\title{
ANGKA KUMAN UDARA RUANG RAWAT INAP ANAK DENGAN DAN TANPA AIR CONDITIONER (AC) DI RUMAH SAKIT
}

\author{
Raimunah, Leka lutpiatina, Jasmadi Joko Kartiko, Wahdah Norsiah
}

Jurusan Analis Kesehatan Poltekkes Kemenkes Banjarmasin Jl Mistar Cokrokusumo 4a Banjarbaru e-mail: leka.zns@gmail.com

Abstract: Air microorganisms can be found in outdoor or indoor air, ventilation is a very important place in the exchange of indoor air. Ventilation system is divided into two, namely natural ventilation and artificial ventilation in the form of Air Conditioner (AC). This study aims to determine the description of the number of germs in the inpatient wards of children using Air Conditioner (AC) and non (AC) at the Hospital in Martapura city area. This type of research is descriptive survey, the population is the inpatient room of children using Air Conditioner (AC) and non (AC). Sampling using purposive sampling technique, that is as much as 8 room. The examination method used is by TPC (Total Plate Count) method. The results showed that the number of airborne bacterial infections using the Air Conditioner (AC) was $406 \mathrm{CFU} / \mathrm{m3}$. The total number of non-living inpatients (AC) is $443 \mathrm{CFU} / \mathrm{m3}$. The standard maximum number of microorganisms (CFU / m3) of treatment room according to Kepmenkes No.1204/ Menkes/SK/X/2004 is 200-500 CFU / m3.

Keyword : Air Conditioner, number of germs, room

Abstrak: : Mikroorganisme udara dapat di temukan pada udara luar ruangan maupun dalam ruangan, ventilasi merupakan tempat yang sangat penting dalam pertukaran udara dalam ruangan. Sistem ventilasi dibedakan menjadi dua yaitu ventilasi alami dan ventilasi buatan berupa Air Conditioner (AC). Penelitian ini bertujuan untuk mengetahui gambaran angka kuman pada ruang rawat inap anak menggunakan Air Conditioner (AC) dan non (AC) di Rumah Sakit di wilayah kota Martapura. Jenis penelitian ini bersifat survey deskriptif, populasi adalah ruang rawat inap anak menggunakan Air Conditioner $(A C)$ dan non (AC). Pengambilan sampel menggunakan teknik purposive sampling, yaitu sebanyak 8 ruangan. Metode pemeriksaan yang digunakan adalah $n$ metode TPC (Total Plate Count). Hasil penelitian menunjukkan jumlah angka kuman udara ruang rawat inap anak menggunakan Air Conditioner (AC) adalah sebanyak 406 $\mathrm{CFU} / \mathrm{m}^{3}$. Jumlah angka kuman udara ruang rawat inap anak non $\left(\mathrm{AC}_{3}\right)$ adalah sebanyak $443 \mathrm{CFU} / \mathrm{m}^{3}$. Standar jumlah maksimum mikroorganisme $\left(\mathrm{CFU} / \mathrm{m}^{3}\right)$ ruang perawatan menurut Kepmenkes No.1204/Menkes/SK/X/2004 adalah sebanyak 200-500 CFU/m². Kata Kunci: Madu Lebah Kelulut (Trigona spp.); Staphylococcus aureus resisten 


\section{PENDAHULUAN}

Polusi adalah masuk atau dimasukkannya makhluk hidup, zat, energi dan komponen lain ke dalam air dan udara oleh kegiatan manusia atau dari alam, sehingga kualitas air dan udara turun yang menyebabkan air dan udara tersebut menjadi kurang atau tidak berfungsi sesuai dengan ketentuannya [1].

Berbagai macam kegiatan industri dan teknologi yang ada saat ini apabila tidak di sertai dengan program pengelolaan limbah yang baik, akan memungkinkan terjadinya pencemaran. Bahan pembuangan terdiri dari beberapa macam komponen baik bersifat organik maupun anorganik. Udara di daerah perkotaan yang mempunyai banyak kegiatan industri dan teknologi serta lalu lintas yang padat udaranya relatif sudah tidak bersih lagi [14].

Udara merupakan campuran beberapa macam gas yang perbandingannya tidak tetap, tergantung pada keadaan suhu udara, tekanan udara dan lingkungan sekitarnya. Secara umum penyebab pencemar udara ada dua macam, yaitu pertama karena faktor internal (secara alamiah) seperti gas pembusukan dari sampah organik, debu yang beterbangan akibat angin, serta abu yang di keluarkan dari letusan gunung, dan lain-lain. Kedua karena faktor eksternal (karena ulah manusia) seperti dari pembakaran bahan fosil, dari kegiatan industri dan pemakaian zat-zat kimia yang di semprotkan ke udara. Pencemaran udara ini dapat tersebar kemana-mana, kemudian masuk ke dalam air atau tanah dan menambah pencemaran air ataupun tanah [12].

Seiring dengan perkembangan zaman saat ini pencemaran udara semakin meningkat. Pencemaran udara adalah masuknya komponen lain dalam udara baik dari alam maupun kegiatan manusia secara langsung dan tidak langsung. Mikroorganisme sering ditemukan di udara, sebenarnya mikroorganisme tidak berkembang biak di udara, tetapi terbawa dari bahan partikel seperti debu dan tetesan cairan [13].

Mikroorganisme di udara dapat di temukan pada udara baik di luar ruangan maupun udara di dalam ruangan, udara luar jarang mengandung kuman patogen sedangkan udara dalam ruangan mengandung kuman patogen yang berasal dari kulit, tangan, pakaian dan dari saluran napas manusia. Jenis bakteri udara yang terbukti mengkontaminasi pada ruang menggunakan Air Conditioner (AC) dan non (AC) adalah Staphylococcus, Streptococcus dan Micrococcus [6]. Staphylococcus aureus merupakan bakteri penyebab infeksi nosokomial utama di rumah sakit. Bakteri ini terdapat pada peralatan medis seperti steteskop [9].

Ventilasi merupakan tempat yang sangat penting dalam pertukaran udara dan kualitas udara dalam ruangan. Adapun sistem ventilasi dibedakan menjadi dua yaitu ventilasi alami dan ventilasi buatan, ventilasi alami seperti jendela dan ventilasi buatan seperti Air Conditioner (AC). Ventilasi alami merupakan tempat terjadinya pertukaran udara dari luar ruangan kedalam ruangan tanpa bantuan alat, mesin dan listrik, sehingga tidak memiliki saringan udara, sedangkan ventilasi buatan merupakan pertukaran udara dengan bantuan alat, mesin dan listrik [13].

Hasil pengamatan sementara Rumah Sakit di wilayah kota Martapura merupakan rumah sakit yang bangunannya sudah lama yaitu mulai tahun 2008, adapun ruangan rawat inap yang di gunakan banyak di tempati oleh orang-orang yang berobat atau dirawat dengan berbagai penyakit dan secara bergantian. Ruangan yang akan di gunakan untuk penelitian adalah ruang rawat inap anak yang 
berdekatan dengan ruang rawat inap penyakit paru.

Penggunaan Air Conditioner (AC) sebagai alternatif untuk mengganti ventilasi alami dapat meningkatkan kenyamanan dan produktivitas kerja, namun Air Conditioner (AC) yang jarang dibersihkan akan menjadi tempat nyaman bagi mikroorganisme untuk menjadi tempat melekat dan berkembang biak. Kondisi tersebut mengakibatkan kualitas udara dalam ruangan menurun dan dapat menimbulkan berbagai gangguan kesehatan dan menimbulkan berbgai macam penyakit [10].

Menurut penelitian Vindrahapsari (2016), tentang jumlah bakteri udara pada ruang $A C$ dan non $A C$ di sekolah dasar, didapatkan hasil jुumlah bakteri pada ruang ber AC berkisar antara $50 \mathrm{koloni} / \mathrm{m}^{3}$ sampai $130 \mathrm{koloni} / \mathrm{m}^{3}$. Dan jumlah bakteri pada ruang non $A C$ berkisar antara $7 \mathrm{koloni} / \mathrm{m}^{3}$ sampai $25 \mathrm{koloni} / \mathrm{m}^{3}$ [13].

Menurut Kepmenkes No.1204/ Menkes/ SK/ X/ 2004 jumlah maksimum mikroorganisme per $\mathrm{m}^{3}$ udara $\left(\mathrm{CFU} / \mathrm{m}^{3}\right)$ pada ruang pemulihan atau perawatan yaitu 200-500 (CFU/m $\left.{ }^{3}\right)$. Penelitian ini bertujuan untuk mengetahui Gambaran angka kuman pada ruang rawat inap anak menggunakan Air Conditioner (AC) dan non (AC) di Rumah Sakit di wilayah kota Martapura.

\section{BAHAN DAN METODE}

Jenis penelitian yang digunakan dalam penelitian ini bersifat survey deskriptif yaitu suatu penelitian yang di lakukan untuk menggambarkan suatu fenomena yakni Gambaran Angka Kuman pada Ruang Menggunakan Air Conditioner (AC) dan Non (AC) di Rumah Sakit Ratu di wilayah kota Martapura.

Populasi dalam penelitian ini adalah ruang rawat inap anak menggunakan Air Conditioner (AC) dan non (AC) di rumah sakit di wilayah kota Martapura. Jumlah populasi sebanyak 14 ruang rawat inap anak, terdiri dari 4 ruang rawat inap anak menggunakan Air Conditioner (AC) kelas 1 dan 10 ruang rawat inap anak non (AC) (6 ruang rawat inap anak kelas 2 dan 4 ruang rawat inap anak kelas 3 ).

Pengambilan sampel menggunakan teknik purposive sampling yaitu pengambilan sampel berdasarkan suatu pertimbangan tertentu ataupun ciri-ciri yang sudah diketahui. Sampel ruangan yang di ambil sebanyak 8 sampel yaitu 4 ruang rawat inap anak menggunakan Air Conditioner (AC) kelas 1 dan 4 ruang rawat inap anak non (AC) kelas 3. Variabel bebas dalam penelitian ini adalah ruang menggunakan Air Conditioner (AC) dan non (AC) Rumah Sakit. Variabel terikat dalam penelitian ini yaitu jumlah angka kuman di udara.

Cara kerja penelitian dengan menentukan titik sampling dengan metode settling plate yaitu pada 5 titik tiap ruangan. Cawan petri diletakkan dengan kondisi terbuka selama 5 menit. Cawan petri dibungkus dengan kertas, kemudian diikat dengan karet sampai erat. Diberi keterangan: waktu pengambilan, lokasi/ tempat, pada saat pengambilan sampel. Dibawa segera ke laboratorium. Plat dimasukkan pada inkubator dengan suhu $37^{\circ} \mathrm{C}$ dan selama $2 \times 24$ jam. Jumlah koloni mikroba 
yang tumbuh dihitung secara langsung atau dengan menggunakan colony counter [13].

Data dari hasil pemeriksaan laboratorium terhadap pemeriksaan jumlah angka kuman pada ruang rawat inap anak ber AC dan non AC di Rumah Sakit di wilayah kota Martapura dianalisis secara deskriptif dan ditabulasikan kemudian hasilnya dibandingkan dengan standar jumlah koloni kuman maksimum.

$$
\text { Jumlah mikroba rata }- \text { rata }=\frac{\text { Jumlah koloni dalam semua cawan petri }}{\text { Banyaknya cawan petri }} \mathrm{CFU} / \mathrm{m}^{3}
$$

\section{HASIL DAN PEMBAHASAN}

Hasil pengukuran suhu ruang rawat inap anak

Tabel 1 hasil pengukuran suhu ruangan

\begin{tabular}{ccccc}
\hline No & $\begin{array}{c}\text { Rung rawat } \\
\text { inap anak }\end{array}$ & $\begin{array}{c}\text { Penggunaan } \\
\text { AC }\end{array}$ & $\begin{array}{c}\text { Hasil } \\
\text { pengukuran } \\
\text { suhu }\left({ }^{0} \mathrm{C}\right)\end{array}$ & $\begin{array}{c}\text { Rata-rata } \\
\text { pengukuran } \\
\text { suhu }\left(\mathrm{C}^{0}\right)\end{array}$ \\
\hline 1 & A & AC & 23,6 & \\
2 & 1B & AC & 24,1 & 23,2 \\
3 & 1C & AC & 21,3 & \\
4 & 1D & AC & 23,8 & \\
5 & 3A & Non AC & 26,8 & \\
6 & 3B & Non AC & 25,3 & 27,3 \\
7 & 3C & Non AC & 25,0 & \\
8 & 3D & Non AC & 32,2 & \\
\hline
\end{tabular}

Hasil pengukuran kelembaban ruang rawat inap anak

Tabel 2 hasil pengukuran kelembaban ruangan

\begin{tabular}{ccccc}
\hline No & $\begin{array}{c}\text { Rung rawat } \\
\text { inap anak }\end{array}$ & $\begin{array}{c}\text { Penggunaan } \\
\text { AC }\end{array}$ & $\begin{array}{c}\text { Hasil } \\
\text { pengukuran } \\
\text { kelembaban } \\
(\%)\end{array}$ & $\begin{array}{c}\text { Rata-rata } \\
\text { pengukuran } \\
\text { kelembaban } \\
(\%)\end{array}$ \\
\hline 1 & 1A & AC & 51,3 & \\
2 & 1B & AC & 56,2 & 51,3 \\
3 & 1C & AC & 48,2 & \\
4 & 1D & AC & 49,8 & \\
5 & 3A & Non AC & 93 & \\
6 & 3B & vol.8, , Januari 2018 & 98 & 92 \\
7 & Non AC & Non AC & 88 & \\
8 & 3D & Non AC & 89 & \\
\hline
\end{tabular}

Hasil pemeriksaan jumlah mikroorganisme 
Tabel 3. hasil perhitungan jumlah mikroorganisme dalam ruangan

\begin{tabular}{cccccc}
\hline Rung & & \multicolumn{3}{c}{ Hasil perhitungan } \\
No & $\begin{array}{c}\text { rawat } \\
\text { inap } \\
\text { anak }\end{array}$ & $\begin{array}{c}\text { Penggunaan } \\
\text { AC }\end{array}$ & $\begin{array}{c}\text { Setiap } \\
\text { ruangan }\end{array}$ & $\begin{array}{c}\text { Jumlah } \\
\text { pasien } \\
\text { (Orang) }\end{array}$ & $\begin{array}{c}\text { jumlah } \\
\text { koloni } \\
\left(\text { CFU/m }{ }^{\circ}\right)\end{array}$ \\
\hline 1 & 1A & AC & 265 & 1 & \\
2 & 1B & AC & 336 & 1 & 406 \\
3 & 1C & AC & 451 & 1 & \\
4 & 1D & AC & 573 & 1 & \\
5 & 3A & Non AC & 426 & 1 & \\
6 & 3B & Non AC & 647 & 6 & 443 \\
7 & 3C & Non AC & 416 & 4 & \\
8 & 3D & Non AC & 281 & 0 & \\
\hline
\end{tabular}

Berdasarkan perhitungan jumlah mikroorganisme di dapat hasil yang menunjukkan bahwa nilai minimal jumlah mikroorganisme yaitu $265 \mathrm{CFU} / \mathrm{m}^{3}$ sedangkan nilai maksimal jumlah mikroorganisme yaitu $647 \mathrm{CFU} / \mathrm{m}^{3}$. Berdasarkan nilai ambang batas yang mengacu pada Kepmenkes No.1204/ Menkes/ SK/ X/ 2004 bahwa jumlah maksimal koloni dalam ruang perawatan/ pemulihan adalah $200-500 \mathrm{CFU} / \mathrm{m}^{3}$ didapat hasil bahwa dari 8 ruangan yang di periksa, ada beberapa ruangan yang tidak memenuhi syarat.

Berdasarkan hasil perhitungan yang telah dilakukan di dapatkan jumlah mikroorganisme pada ruang rawat inap anak menggunakan AC yaitu berkisar antara $265 \mathrm{CFU} / \mathrm{m}^{3}$ sampai $573 \mathrm{CFU} / \mathrm{m}^{3}$, sedangkan jumlah mikroorganisme pada ruang rawat inap anak non AC berkisar antara $281 \mathrm{CFU} / \mathrm{m}^{3}$ sampai $647 \mathrm{CFU} / \mathrm{m}^{3}$. Berdasarkan nilai ambang batas yang mengacu pada Kepmenkes No.1204/ Menkes/ SK/ X/ 2004 bahwa jumlah maksimal koloni dalam ruang perawatan/pemulihan adalah 200-500 CFU $/ \mathrm{m}^{3}$. Dan di dapatkan hasil bahwa ada beberapa ruang perawatan yang tidak memenuhi syarat. Yaitu ruang rawat inap anak menggunakan AC pada kelas 1 ruangan $D$ dengan jumlah mikroorganisme sebanyak $573 \mathrm{CFU} / \mathrm{m}^{3}$, sedangkan pada ruang rawat inap anak non AC ruangan yang tidak memenuhi syarat yaitu pada kelas 3 ruangan $B$ dengan jumlah mikroorganisme sebanyak $647 \mathrm{CFU} / \mathrm{m}^{3}$.

Berdasarkan hasil wawacara yang di lakukan dengan petugas kebersihan ruang rawat inap anak yang mengatakan bahwa kebersihan ruangan dilakukan setiap dua kali

sehari, yaitu pada pagi dan sore hari. Berdasrkan hasil perhitungan yang telah

dilakukan di dapatkan hasil bahwa jumlah mikroorganisme yang paling banyak yaitu pada ruang rawat inap anak non $\mathrm{AC}$ daripada ruang rawat inap anak menggunakan AC. Banyaknya jumlah mikroorganisme pada ruang non AC disebabkan karena 
banyaknya penghuni dalam ruangan tersebut, dimana pada saat pengambilan sampel jumlah pasien dan keluarganya dalam satu ruang rawat inap anak non (AC) yaitu ruang rawat inap anak kelas $3 \mathrm{~A}$ dengan jumlah pasien satu orang, kelas 3B dengan jumlah pasien sebanyak 6 orang, kelas $3 C$ dengan jumlah pasien yaitu 4 orang, kelas 3D dimana pada saat pengambilan sampel saat itu ruangan sedang kosong, tidak ada pasien yang di rawat dalam ruang itu. Menurut Vindrahapsari (2015), banyaknya benghuni dalam ruangan sangat berpengaruh terhadap penyebaran bakteri dalam ruangan. Semakin banyak penghuni maka udara dalam ruangan semakin panas, dan bakteri juga bisa terbawa oleh orang dan menyebar ke udara sekitar ruangan sehingga mengkontaminasi udara [13].

Menurut Vindrahapsari, 2015, AC mempunyai filter yang di gunakan di dalam AC yaitu untuk mencegah penyebaran mikroorganisme, filter AC mengumpulkan polutan, dalam proses itu mikroorganisme dapat berkembang biak pada filter AC jika tidak di bersihkan secara teratur dan menyebarkan bakteri ke udara [13]. Menurut Djojodibroto dalam Vindrahapsari, 2015, mikroorganisme hidup pada pipa AC yang menyalurkan udara dingin ke ruangan [13]. Penggunaan AC yang mewajibkan tertutupnya seisi ruangan dapat menyebabkan pertumbuhan mikroorganisme semakin subur. Banyaknya jumlah mikroorganisme pada ruang AC disebabkan karena pembersihan AC yang tidak teratur, sehingga menjadi tempat nyaman untuk mikroorganisme tumbuh dan berkembang biak dalam AC tersebut. Bakteri yang terbukti mengkontaminasi udara ruang menggunakan AC menurut penelitian Iswadi dkk 2014 adalah Staphylococcus dan Pseudomonas [16].

Staphylocccus aureus adalah bakteri patogen yang menjadi penyebab infeksi nosokomial dan juga keracunan makanan. Penyebaran bakteri ini diudara dapat mengkontaminasi pangan, seperti halnya pada saos yang tercemar Staphylococcus aureus [3]. Penelitian lain di rumah sakit menunjukkan adanya Staphylococcus aureus sebanyak 14(52\%) sampel dari 27 sampel swab hidung perawat [4]. Keberadaan bakteri pada hidung Perawat memungkinkan bakteri juga terdapat pada udara ruang perawatan, disamping itu bakteri mempunyai daya tahan tinggi terhadap lingkungan. Staphylococcus aureus juga bertahan hidup pada media dengan $\mathrm{NaCl} 10 \%$ [2].

Pseudomonas aeruginosa yang terdapat di udara ruang perawatan akan menimbulkan masalah bagi pasien dengan luka bakar dan pasien dengan penurunan daya tahan tubuh. Sebuah penelitian menunjukkan adanya Pseudomonas aeruginosa pada kultur darah pasien bakteremia di rumah sakit [8].

Hasil pengukuran suhu pada ruang rawat inap anak menggunakan $\mathrm{AC}$ dan non AC yaitu berkisar antara $21,3^{0} \mathrm{C}$ sampai $32,2^{\mathrm{C}} \mathrm{C}$, berdasarkan surat keputusan menteri kesehatan RI No.1405/Menkes/SK/XI/2002 nilai tersebut ada yang masuk sesuai dengan ambang batas dan ada yang melebihi ambang batas dari setiap ruangan, adapun nilai ambang batas suhu dalam ruangan yaitu $18^{0} \mathrm{C}-28^{0} \mathrm{C}$ namun masih berada pada suhu optimum yang di butuhkan bakteri. Menurut Harti, 2015, suhu optimum yang di butuhkan bakteri $20^{\circ} \mathrm{C}$ sampai $37^{0} \mathrm{C}$ [15]. Sehingga dengan suhu ruang rawat inap tersebut bakteri masih tetap dapat tumbuh. Sumber bakteri dalam ruangan dapat berasal dari beberapa faktor lain yang tidak diteliti dalam penelitian ini yaitu adanya karpet dan tirai dalam ruangan, serta faktor kebersihan ruangan yang sangat mempengaruhi keberadaan mikroorganisme.

Penggunaan AC pada suatu ruangan yaitu untuk mengurangi suhu udara yang 
panas dalam ruangan tersebut, dengan penggunaan AC mengharuskan tertutupnya seisi ruangan dan menyebabkan tidak ada pertukaran udara dari luar ruangan ke dalam ruangan, sehingga kulitas udara dalam ruangan menjadi buruk, terutama AC yang jarang di bersihkan akan menyebabkan AC terkontaminasi oleh mikroorganisme dan tersebar ke seluruh ruangan. Menurut Siregar, dkk. dalam Vindrahapsari, 2015, sedangkan pada ruang non AC di pengaruhi dari jumlah penghuni dalam ruangan, semakin banyak penghuni maka udara dalam ruangan semakin panas, dan bakteri juga bisa terbawa oleh orang dan menyebar ke udara sekitar ruangan sehingga mengkontaminasi udara ruangan [13].

Hasil pengukuran kelembaban ruang rawat inap anak yaitu berkisar antara $48,2 \%$ sampai $98 \%$. Ruangan dengan kelembaban tertinggi $(98 \%)$ menghasilkan angka kuman terbesar yaitu $647 \mathrm{CFU} / \mathrm{m}^{3}$. Menurut Mukono, 2010, kelembaban optimum yang di butuhkan mikroorganisme di atas $85 \%$. Kelembaban suatu faktor yang mempengaruhi banyaknya jumlah mikroorganisme dalam ruangan. Kelembaban udara yang relatif rendah yaitu kurang dari $20 \%$ dapat menyebabkan kekeringan selaput lendir membran, sedangkan kelembaban tinggi akan meningkatkan pertumbuhan mikroorganisme.

Menurut Lisyastuti, 2010, kelembaban dalam ruangan di sebabkan karena adanya uap air dalam ruangan tersebut, dengan adanya AC di gunakan untuk menyedot percikan dari air dalam ruangan dan di buang ke luar ruangan, sehingga kelembaban suatu ruangan tersebut relatif rendah dan dapat mengurangi jumlah mikroorganisme dalam ruangan, karena kelembaban yang relatif rendah dapat menyebabkan kekeringan selaput lendir membran dari mikroorganisme tersebut. Sedangkan pada ruang non AC di dapatkan kelembaban yang relatif tinggi, karena banyaknya uap air yang terdapat dalam ruangan tersebut, ruangan yang lembab merupakan media yang baik bagi pertumbuhan mikroorganisme [7].

\section{KESIMPULAN}

Jumlah angka kuman rata-rata ruang $\mathrm{AC}$ adalah $406 \mathrm{CFU} / \mathrm{m}^{3}$ dan jumlah angka kuman rata-rata ruang non $\mathrm{AC}$ adalah $443 \mathrm{CFU} / \mathrm{m}^{3}$ dibandingkan dengan jumlah maksimum mikroorganisme yaitu berkisar antara 200-500 CFU/m ${ }^{3}$, angka kuman masih memenuhi syarat.

\section{DAFTAR PUSTAKA}

[1] R. Achmad, Kimia Lingkungan. Jakarta: Andi, 2004..

[2] Amalia, R. D. Dwiyanti, and Haitami, "Daya Hambat Nacl Terhadap Pertumbuhan Staphylococcus aureus," Med. Lab. Tecnol. J, vol. 2, n, p. pp. 42-45, 2016.

[3] R. D. Dwiyanti and L. Lutpiatina, "Mutu Bakteriologis Saus Tomat Pentol Di Banjarbaru," Med. Lab. Tecnol. J, vol. 2, no, pp. 1-5, 2016.

[4] R. D. Dwiyanti, A. Muhlisin, and A. Muntaha, "MRSA dan VRSA Pada Paramedis RSUD Ratu Zalecha Martapura," Med. Lab. Technol. J., vol. 1, no. 1, pp. 27-33, 2015.

[5] A. S. Harti, Mikrobiologi Kesehatan. Yogyakarta: Andi, 2015.

[6] H. Iswadi, Samingan, "Identifikasi Jenis Bakteri Udara Di Ruangan Bersistem HVAC (Heating Ventilation And Air Conditioning)," 2014

[7] E. Lisyastuti, "Jumlah koloni mikroorganisme udara dalam Ruang dan 
hubungannya dengan kejadian sick Building syndrome (sbs) pada pekerja balai besar Teknologi kekuatan struktur (b2tks) bppt Di kawasan puspiptek serpong tahun 2010," 2010.

[8] L. Lutpiatina, "Pewarnaan Gram Buffy Coat Untuk Deteksi Awal Pasien Bakteremia," Med. Lab. Technol. J., vol. 1, no. 1, pp. 38-46, 2015.

[9] L. Lutpiatina, "Cemaran Staphylococcus aureus dan Pseudomonas aerogenosa Pada Stetoskop dirumah sakit.," J. Teknol. Lab., vol. 6, no, 2017.

[10] Moerdjoko, "Kaitan Sistem Ventilasi Bangunan Dengan Keberadaan Mikroorganisme Udara.," Puslit J., vol. 32, n, pp. 89-94, 2004.

[11] Mukono, Toksikologi Lingkungan. Surabaya: Airlangga Universitas Press, 2010.

[12] A. . Sastrawijaya, Pencemaran Lingkungan. Jakarta: PT. Rineka Cipta, 2000.

[13] R. T. Vindrahapsari, "Kondisi Fisik dan Jumlah Bakteri pada Ruangan AC dan Non AC di Sekolah Dasar.," Universitas Muhammadiyah Semarang, 2016. 